\title{
Synthesis of Polyols from Mabea fistulifera Mart. (Euphorbiaceae) Oil
}

\author{
Julieta J. da Silveira Neta, ${ }^{*, a, b}$ Carlos J. da Silva, ${ }^{b}$ Róbson R. Teixeira, ${ }^{b}$ César Reis, ${ }^{b}$ \\ Efraim L. Reis ${ }^{b}$ and Amanda M. Teixeira ${ }^{b}$ \\ ${ }^{a}$ Embrapa Amazônia Oriental, Trav. Dr. Enéas Pinheiro s/n, 66095-100 Belém-PA, Brazil \\ ${ }^{b}$ Departamento de Química, Universidade Federal de Viçosa, Av. P. H. Rolfs s/n, 36570-000 Viçosa-MG, Brazil
}

\begin{abstract}
Mabea fistulifera Mart. (Euphorbiaceae) é uma planta arbórea com altura variando de 5 a $14 \mathrm{~m}$, típica da vegetação secundária de terrenos arenosos, principalmente de savana. No Brasil, é encontrada nos estados do Rio de Janeiro, Minas Gerais e São Paulo. O processo de extração Soxhlet das sementes desta espécie vegetal com hexano produziu um óleo rico em triacilglicerídeos dos ácidos linolênico e linoléico e que apresenta índice de iodo igual a 182,15 g de $\mathrm{I}_{2}$ per $100 \mathrm{~g}$ de óleo. Descreve-se neste trabalho a produção de um biopoliol a partir do óleo de M. fistulifera Mart., empregando-se um processo de hidroxilação in situ. Ensaios univariados permitiram determinar o tempo ótimo de reação como sendo $720 \mathrm{~min}$. Além disso, realizou-se ainda um planejamento fatorial $2^{2}$ composto central (CCD) contendo 12 ensaios experimentais que permitiram investigar diferentes razões molares dos reagentes empregados na síntese do biopoliol, bem como avaliar sua aplicabilidade como matéria-prima na síntese de poliuretanos com característica rígida.
\end{abstract}

Mabea fistulifera Mart. (Euphorbiaceae) is an arboreal plant with height varying from 5 to $14 \mathrm{~m}$, typical of secondary vegetation of sandy lands, mainly savannah. In Brazil, it is found in the Rio de Janeiro, Minas Gerais and São Paulo States. Soxhlet extraction of M. fistulifera seeds with hexane provided an oil rich in tryacylglycerides of linolenic and linoleic acids, presenting iodine index of $182.15 \mathrm{~g}$ of $\mathrm{I}_{2}$ per $100 \mathrm{~g}$ of oil. In this study, the synthesis of polyols from M. fistulifera oil using an in situ hydroxylation procedure is described. Univariate assays were applied to determine the optimal reaction time of $720 \mathrm{~min}$. In addition, a $2^{2}$ factorial central composite design was carried out containing 12 experimental assays that allowed the investigation of different molar ratios of the reagents used in polyol synthesis, as well as the applicability of polyols for the preparation of rigid polyurethanes.

Keywords: Mabea fistulifera Mart, polyol, univariate assays, hydroxylation

\section{Introduction}

Oil reserve depletion and increasing market prices have led researchers worldwide to seek renewable resources to replace petrochemical derivatives. ${ }^{1}$ Vegetable oils such as soybean, ${ }^{2,3}$ rape $^{4}$ and peanut ${ }^{5,6}$ are promising petrochemical alternatives since they are relatively inexpensive and renewable sources. ${ }^{7}$

Mabea (Euphorbiaceae) is a neo-tropical genus composed of 50 species, ${ }^{8}$ including Mabea fistulifera Mart. (commonly known as "canudo-de-pito"), an arboreal plant with height varying from 5 to $14 \mathrm{~m}$, typical of secondary vegetation of sandy lands, mainly savannah (Figure 1). In Brazil, M. fistulifera is found in the Rio de Janeiro,

*e-mail: julieta_neta@yahoo.com.br,julieta@cpatu.embrapa.br

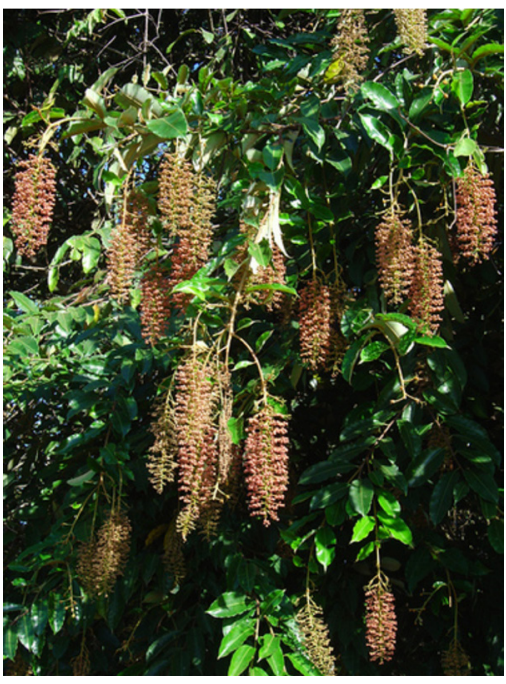

Figure 1. The plant species Mabea fistulifera Mart. 
Minas Gerais and São Paulo States. ${ }^{9}$ It is usually found aggregated on forest edges and areas with strong anthropogenic impact. The flowering occurs from February to June, peaking between April and May, corresponding to the onset of the dry season. Since it occurs during periods of food scarcity, many animals such as monkeys, bats, skunks, birds and insects use its abundantly produced pollen and nectar as alternative feed sources. ${ }^{10}$

Soxhlet extraction of $M$. fistulifera seeds with hexane provides oil percentages varying from 35 to $40 \%$ in relation to the weight of dried seeds. ${ }^{11}$ M. fistulifera oil is mainly composed of tryacylglycerides from unsaturated fatty acids.

Plant oils are an excellent renewable source of raw material for the synthesis of polyols, which can be used in the preparation of polymeric materials, such as polyesters and polyurethanes. ${ }^{7}$ Polyol production from vegetable matrices is obtained by replacing the unsaturated bonds of the oil constituents by hydroxyl groups. ${ }^{12}$ Different methodologies, such as ring opening of epoxides with alcohols, ${ }^{13,14}$ ozonolysis, followed by hydrogenation ${ }^{15}$ and in situ hydroxylation reactions, ${ }^{12,16}$ have been used for the preparation of polyols from triacylglycerides contained in vegetable oils. In situ hydroxylation of fatty acids is carried out by reacting the oil with hydrogen peroxide/formic acid ${ }^{17-19}$ or hydrogen peroxide/glacial acetic acid. ${ }^{20,21}$ In these cases, performic acid or peracetic acid is generated, promoting epoxidation of the double bonds present in the oil molecules. An excess of formic acid or acetic acid is used to open the epoxide thus formed. The net result is an in situ hydroxylation of the unsaturated molecules present in the oil. Depending on the experimental conditions adopted, the mono and polyfunctional alcohols obtained may present different hydroxyl indices, making polyol a versatile product for the synthesis of polyurethane resins with diverse properties and applications.

In this study, the results obtained from polyol synthesis from M. fistulifera oil using in situ hydroxylation reaction are described. In addition, a $2^{2}$ factorial central composite design was carried out containing 12 experimental assays investigating several molar ratios of the reagents used in polyol synthesis, as well as the applicability of polyols for the preparation of rigid polyurethanes. To the best of our knowledge, there are no reports on the application of M. fistulifera oil for the production of polyols.

\section{Experimental}

\section{General methodology}

All reagents used were PA grade. Glacial acetic acid, formic acid, hydrogen peroxide solution, sulfuric acid, sodium bisulfite, sodium carbonate and anhydrous sodium sulfate were purchased from Vetec (Rio de Janeiro, Brazil). Toluene and hexane were purchased from Merck.

Infrared (IR) spectra were obtained in $\mathrm{KBr}$ pellets containing $1 \%(\mathrm{~m} / \mathrm{m})$ of the compound, using a Perkin Elmer 1000 spectrometer scanning from 500 to $4000 \mathrm{~cm}^{-1}$. Hydrogen nuclear magnetic resonance $\left({ }^{1} \mathrm{H}\right.$ NMR, $300 \mathrm{MHz}$ ) spectra were obtained using Varian Mercury 300 spectrometer. Deuterated chloroform $\left(\mathrm{CDCl}_{3}\right)$ was used as solvent with tetramethylsilane (TMS) as an internal standard $(\delta=0)$.

\section{Plant material}

M. fistulifera Mart. seeds were collected before reaching their maturation period, in early October 2010 in Viçosa City (Minas Gerais State, Brazil). The seeds were covered with a screen and sun-dried until dehiscence.

\section{Extraction procedure}

Seeds were extracted for $2 \mathrm{~h}$ with hexane under reflux in a Soxhlet extractor. The mixture was filtered and washed with hexane. The filtrate obtained was concentrated under reduced pressure in a rotary evaporator, yielding yellowish oil $(35 \%, \mathrm{~m} / \mathrm{m})$.

\section{GC-MS analyses}

M. fistulifera oil was transesterified using a standard procedure $^{22}$ and analyzed by gas chromatography-mass spectrometry (GC-MS). Qualitative analyses were conducted with a Shimadzu (Kyoto, Japan) gas chromatograph-mass spectrometer (QP 5000 and Classs-5000 software, version 1.2) with an auto sampler and workstation. A fused silica column coated with the DB-5 stationary phase ( $30 \mathrm{~m} \times 0.2 \mathrm{~mm}$ internal diameter, film thickness $0.25 \mu \mathrm{m}$, $\mathrm{J} \& \mathrm{~W}$ Scientific) was used. Initial oven temperature of $60{ }^{\circ} \mathrm{C}$ was held for $5 \mathrm{~min}$, programmed to increase at $2{ }^{\circ} \mathrm{C} \mathrm{min}^{-1}$ to $240{ }^{\circ} \mathrm{C}$, and held at this temperature for $30 \mathrm{~min}$. Injector temperature was $220^{\circ} \mathrm{C}$. Helium was used as the carrier gas at a flow rate of $1.0 \mathrm{~mL} \mathrm{~min}^{-1}$. Injection volume was $1 \mu \mathrm{L}\left(1 \%\right.$ solution in $\left.\mathrm{CH}_{2} \mathrm{Cl}_{2}\right)$, with a split ratio of $1: 10$. The column pressure was $100 \mathrm{kPa}$. Mass detector conditions were as follows: source temperature of $240{ }^{\circ} \mathrm{C}$, electron impact (EI) mode at $70 \mathrm{eV}$, scan rate of $1 \mathrm{scan} \mathrm{s}^{-1}$ and mass acquisition range 29-450 $\mathrm{u}$.

The components were identified by comparing their retention indexes (RI) relative to a linear standard alkane series $\left(\mathrm{C}_{9}-\mathrm{C}_{24}\right)$ and by comparing their mass spectra with reference data from the equipment database (Wiley 330000 ) and from the literature. ${ }^{23}$ 


\section{Determination of physicochemical properties of M. fistulifera} oil

Acid index, ${ }^{24}$ hydroxyl index (ASTM D 2849 Method A) $)^{25}$ and iodine index ${ }^{26}$ were determined according to the literature procedures.

\section{Typical procedure for the preparation of $M$. fistulifera polyol}

To a round bottom flask, $5.00 \mathrm{~g}(0.36 \mathrm{mmol}$ of double bounds) of $M$. fistulifera oil, $9.30 \mathrm{~mL}(0.162 \mathrm{~mol})$ of glacial acetic acid, $20 \mathrm{~mL}$ of toluene and 3 drops of concentrated sulfuric acid were added. The reaction mixture was stirred at $30{ }^{\circ} \mathrm{C}$ and $5.30 \mathrm{~mL}$ of a $\mathrm{H}_{2} \mathrm{O}_{2}$ aqueous solution $(30 \%, \mathrm{v} / \mathrm{v})$ were slowly added to the mixture at this temperature. The temperature was then raised to $60{ }^{\circ} \mathrm{C}$ and the system was connected to a reflux condenser. After $720 \mathrm{~min}$, the heating was interrupted and an aqueous solution of sodium bisulfide $(10 \%, \mathrm{~m} / \mathrm{v})$ was added, with stirring continuing for $20 \mathrm{~min}$. The mixture was transferred to a separatory funnel with diethyl ether, and the layers were separated. The organic layer was washed with aqueous sodium carbonate $(10 \%, \mathrm{~m} / \mathrm{v})$ until neutral, dried with anhydrous sodium sulfate, filtered and concentrated under reduced pressure.

\section{Univariate assays}

Influence of the molar ratios of reagents on polyol synthesis from $M$. fistulifera oil

Screening experiments were performed to verify the influence of different molar ratios of the reagents (Table 1) on polyol synthesis. The formulations were constituted of M. fistulifera oil, acetic or formic acid, and water. The amounts of all reagents were divided by the amount of oil in mol to obtain a ratio of $1: Z: Y$, where 1 is the number of mol of double bonds present in the oil, $\mathrm{Z}$ is the number of mols of acetic or formic acid, which varied according to

Table 1. Reaction conditions for univariate studies to evaluate different polyol formulations

\begin{tabular}{lccc}
\hline & $\mathrm{Oil}^{\mathrm{b}}$ & Acetic acid & $\mathrm{H}_{2} \mathrm{O}_{2}$ \\
& 1 & $\mathrm{Z}$ & $\mathrm{Y}$ \\
\hline $\mathrm{A}$ & 1 & - & - \\
$\mathrm{B}$ & 1 & 1.8 & 4.75 \\
$\mathrm{C}$ & 1 & 3.0 & 1.5 \\
$\mathrm{D}$ & 1 & 4.5 & 1.5 \\
$\mathrm{E}^{\mathrm{a}}$ & 1 & 4.5 & 1.5 \\
\hline
\end{tabular}

${ }^{\mathrm{a}}$ For ratio E, formic acid was used instead of glacial acetic acid; ${ }^{\mathrm{b}} \mathrm{mol}$ of double bonds of oil per $\mathrm{g}$ of oil. the experiment, and $\mathrm{Y}$ is the number of mol of hydrogen peroxide, which also varied according to the experiment. The reaction time was $720 \mathrm{~min}$ and the temperature was adjusted to $60{ }^{\circ} \mathrm{C}$ after the addition of hydrogen peroxide aqueous solution $(30 \%, \mathrm{v} / \mathrm{v})$.

Influence of time on polyol synthesis from $M$. fistulifera oil

The optimized reaction time of $720 \mathrm{~min}$ mentioned above was based on a univariate study to evaluate the influence of the reaction time on the transformation of $M$. fistulifera oil into polyol. The reaction times investigated were $60,120,240,360,480$ and $720 \mathrm{~min}$. In the univariate study, $5.00 \mathrm{~g}(0.036 \mathrm{~mol})$ of $M$. fistulifera oil, $9.30 \mathrm{~mL}$ $(0.162 \mathrm{~mol})$ of glacial acetic acid and $5.30 \mathrm{~mL}(0.054 \mathrm{~mol})$ of aqueous $\mathrm{H}_{2} \mathrm{O}_{2}(30 \%$, v/v) were used. The temperature of the reaction was adjusted to $60{ }^{\circ} \mathrm{C}$ after the addition of hydrogen peroxide aqueous solution.

\section{Optimization of $M$. fistulifera polyol synthesis}

After an initial univariate screening of the experimental conditions, the optimization was carried out using a $2^{2}$ factorial central composite design (CCD) aiming to study different molar ratios of the reagents (oil double bonds, glacial acetic acid and hydrogen peroxide). This experiment was conducted in four replications at the center point, totalizing 12 assays. The levels of the variables codified $+1,0,-1$ and \pm 1.41 corresponded to the highest, middle, lower and axial values, respectively. The values codified $\mathrm{X}_{\mathrm{i}}$ can be decodified for the experimental values of the levels of the variables to be studied, using equation $1^{27}$

$X_{i}=\frac{C-\bar{C}}{\Delta C / 2}$

where $X_{i}$ is the variable coded for CCD design $(I=1,2,3 \ldots)$, $\mathrm{C}$ is the original variable, $\overline{\mathrm{C}}$ is the average between the levels $(+)$ and ( - ) of the original variable, which corresponds to the value at level zero, and $\Delta \mathrm{C}$ is the difference between the levels (+) and (-) in the original variables.

In this factorial experiment, reactions were performed under the following conditions: 3 drops of concentrated sulfuric acid, $20 \mathrm{~mL}$ of toluene, $720 \mathrm{~min}$ and temperature adjusted to $60{ }^{\circ} \mathrm{C}$ after addition of hydrogen peroxide aqueous solution $(30 \%, \mathrm{v} / \mathrm{v})$. The codified and decodified variables $\left(\mathrm{X}_{\mathrm{i}}\right)$ of the factorial experiment are shown in Table 2 .

After the assays were carried out and the hydroxyl

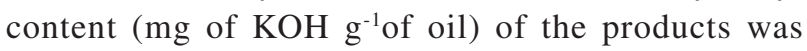
obtained, the response surface could be generated using the Statistics 7.0 software. 
Table 2. $2^{2}$ Factorial central composite design (CCD)

\begin{tabular}{cccccc}
\hline \multicolumn{2}{c}{ Decodified variables } & reagent ratio & & \multicolumn{2}{c}{ Codified variables } \\
\cline { 1 - 2 } \cline { 5 - 6 } Assay & $\begin{array}{c}\text { Acetic } \\
\text { acid }\end{array}$ & $\begin{array}{c}\text { Hydrogen } \\
\text { peroxide }\end{array}$ & & $\mathrm{X}_{1}$ & $\mathrm{X}_{2}$ \\
\hline 1 & 3.5 & 1.0 & & -1 & -1 \\
2 & 5.5 & 1.0 & & 1 & -1 \\
3 & 3.5 & 2.0 & & -1 & 1 \\
4 & 5.5 & 2.0 & & 1 & 1 \\
5 & 3.1 & 1.5 & & -1.414 & 0 \\
6 & 5.9 & 1.5 & & 1.414 & 0 \\
7 & 4.5 & 0.8 & & 0 & -1.414 \\
8 & 4.5 & 2.2 & & 0 & 1.414 \\
9 & 4.5 & 1.5 & & 0 & 0 \\
10 & 4.5 & 1.5 & 0 & 0 \\
11 & 4.5 & 1.5 & 0 & 0 \\
12 & 4.5 & 1.5 & 0 & 0 \\
\hline
\end{tabular}

${ }^{\mathrm{a}}$ The ratio of $M$. fistulifera oil was set at $1\left(0.036 \mathrm{~mol}\right.$ of double bonds $\mathrm{g}^{-1}$ of oil).

\section{Results and Discussion}

\section{Characterization of $M$. fistulifera oil}

The physicochemical properties of the M. fistulifera oil are presented in Table 3. The iodine index of this oil is higher than that of soybean (120-141 $\mathrm{g}$ of $\mathrm{I}_{2}$ per $100 \mathrm{~g}$ of oil), cotton (103-115 g of $\mathrm{I}_{2}$ per $100 \mathrm{~g}$ of oil) and castor (81-91 $\mathrm{g}$ of $\mathrm{I}_{2}$ per $100 \mathrm{~g}$ of oil) oils. ${ }^{28}$ Thus, the M. fistulifera oil is rich in polyunsaturated fatty acids, an essential characteristic for polyol production. The acidity index was higher than that reported for soybean oil $(0.20 \mathrm{mg}$ of $\mathrm{KOH} \mathrm{g}{ }^{-1}$ of oil). ${ }^{29}$ This fact is related to the increased percentage of free fatty acids likely due to oil deterioration during storage or processing, enzyme action, moisture or high temperatures. ${ }^{30}$

Table 3. Physicochemical properties of $M$. fistulifera oil experimentally determined

\begin{tabular}{lc}
\hline Physicochemical property & Experimental value \\
\hline $\mathrm{AI} \mathrm{mg} \mathrm{of} \mathrm{KOH} \mathrm{g}^{-1}$ of oil & 2.22 \\
$\mathrm{II} \mathrm{g}$ of $\mathrm{I}_{2}$ per $100 \mathrm{~g}$ of oil & 182.15 \\
$\mathrm{I}_{\mathrm{OH}} \mathrm{mg} \mathrm{of} \mathrm{KOH} \mathrm{g}^{-1}$ of oil & 2.18 \\
\hline
\end{tabular}

AI: acidity index; II: iodine index; $\mathrm{I}_{\mathrm{OH}}$ : hydroxyl index.

The GC-MS analysis showed that the major component of the M. fistulifera oil is tryacylglyceride of linolenic acid, followed by tryacylglyceride of linoleic acid (Table 4). These fatty acids have three and two double bonds,
Table 4. Compounds identified in M. fistulifera oil by GC-MS

\begin{tabular}{lcc}
\hline Substance & Formula & mass \% \\
\hline Methyl (2E, 4Z)-deca-2,4-dienoate & $\mathrm{C}_{11} \mathrm{H}_{18} \mathrm{O}_{2}$ & 1.10 \\
Methyl palmitate & $\mathrm{C}_{17} \mathrm{H}_{34} \mathrm{O}_{2}$ & 4.90 \\
Pentadecane & $\mathrm{C}_{15} \mathrm{H}_{32}$ & 0.40 \\
Methyl linoleate & $\mathrm{C}_{19} \mathrm{H}_{34} \mathrm{O}_{2}$ & 18.30 \\
Methyl linolenate & $\mathrm{C}_{19} \mathrm{H}_{32} \mathrm{O}_{2}$ & 69.00 \\
Methyl stearate & $\mathrm{C}_{19} \mathrm{H}_{38} \mathrm{O}_{2}$ & 4.20 \\
Heptadecane & $\mathrm{C}_{17} \mathrm{H}_{36}$ & 0.60 \\
Icosane & $\mathrm{C}_{20} \mathrm{H}_{42}$ & 1.50 \\
\hline
\end{tabular}

respectively, confirming the high potential of the oil for polyol synthesis.

The M. fistulifera oil was also examined by IR and NMR analyses. Diagnostic bands for $=\mathrm{CH}\left(3014 \mathrm{~cm}^{-1}\right)$, $\mathrm{C}=\mathrm{O}\left(1751 \mathrm{~cm}^{-1}\right)$ and $\mathrm{C}=\mathrm{C}\left(1645 \mathrm{~cm}^{-1}\right)$ were identified in the IR spectrum of $M$. fistulifera oil.

\section{Univariate assays}

Influence of the molar ratios of the reagents on polyol preparation

The synthesis of the polyols from the M. fistulifera oil was carried out via in situ hydroxylation. In this study, the oil was treated with a mixture of acetic acid (or formic acid)/ $\mathrm{H}_{2} \mathrm{O}_{2}$ at $60{ }^{\circ} \mathrm{C}$. Different experiments were conducted to evaluate the influence of different formulations (Table 1), as well as of the reaction time on the efficiency of converting the oil into polyols.

To determine the best molar ratio of the M. fistulifera oil, acetic acid (or formic acid) and $\mathrm{H}_{2} \mathrm{O}_{2}$, to maximize the conversion of the oil into polyols, different experiments were carried out, varying the ratio of oil/acetic acid (or formic acid)/ $\mathrm{H}_{2} \mathrm{O}_{2}$. Reactions were monitored by IR spectroscopy. The presence of a stretching band of $=\mathrm{CH}\left(3014 \mathrm{~cm}^{-1}\right)$ in the IR spectrum of the $M$. fistulifera crude oil was noticed. This band is absent in the IR spectra in the analysis of the products obtained in the reactions in which the oil was submitted to different molar ratios of $\mathrm{H}_{2} \mathrm{O}_{2}$ /acetic acid (or formic acid). In addition, the treatment of the M. fistulifera oil, using different $\mathrm{H}_{2} \mathrm{O}_{2}$ /acetic acid (or formic acid) ratios, resulted in a decrease in the intensity of the absorptions related to the stretching of the $\mathrm{C}=\mathrm{C}$ bond at $1645 \mathrm{~cm}^{-1}$. Bands emerging at 791 and $820 \mathrm{~cm}^{-1}$, assigned to the stretching of $\mathrm{C}-\mathrm{O}$ bonds of the epoxide rings were also observed.

IR spectra stressed the process of epoxidation of the double bonds of the tryacylglycerides present in the M. fistulifera oil. This fact could be confirmed by ${ }^{1} \mathrm{H}$ NMR spectroscopy. 
${ }^{1} \mathrm{H}$ NMR spectrum obtained by analyzing the mixture of products produced from the reaction using the ratio of oil/acetic acid $/ \mathrm{H}_{2} \mathrm{O}_{2}$ (proportion 1:1.8:4.75) did not present signals corresponding to the olefinic hydrogens. Hydrogen signals of the oxirane groups were observed in the region of $\delta$ 2.8-3.2 $(-\mathrm{C} \underline{\mathrm{H}}(\mathrm{O}) \mathrm{C} \underline{\mathrm{H}}-)$ ) along with the proton signals of the methylene groups between the oxirane rings (1.75 ppm). Other changes were observed at approximately $\delta 2.0$, with the decrease of the signals relative to allylic hydrogen atoms, when compared with the spectrum of the crude oil and at $\delta 1.05$, corresponding to the signals to the hydrogen atoms of the methyl groups of fatty acid chains with oxirane ring on carbons 15 and 16, derived from linolenic acid epoxidation. ${ }^{31}$

The increase in the amount in mol of acetic acid (or formic acid) favors the epoxide ring opening with concomitant polyol formation. This fact is evidenced by the emergence of a broad band at $3440 \mathrm{~cm}^{-1}$, corresponding to the stretching of the hydroxyl group. The epoxide ring opening reaction was confirmed by ${ }^{1} \mathrm{H}$ NMR spectroscopy. The analysis of the mixture of products from the reaction performed with the oil/acetic acid $/ \mathrm{H}_{2} \mathrm{O}_{2}$ ratio of 1:4.5:1.5 showed the absence of olefinic hydrogen signals of the tryacylglycerols. In addition, the disappearance of the signal relative to the hydrogen atoms of the methylene groups between the oxirane rings at $\delta 1.75$ in the epoxidized material was verified, showing that the rings formed during the epoxidation reaction were ruptured to produce polyol. The appearance of signals between $\delta 3.2-4.0 \mathrm{ppm}$ corresponding to hydrogens attached to carbons attached to hydroxyl groups $\left(-\underline{\mathrm{H}}(\mathrm{OH})-\right.$ ) is significant, ${ }^{32}$ confirming the incorporation of $\mathrm{OH}$ groups in the oil constituents containing double bonds.

It must be emphasized that identical oil/acid/ $\mathrm{H}_{2} \mathrm{O}_{2}$ ratios were used in experiments $\mathrm{D}$ and $\mathrm{E}$ (Table 1). In experiment $\mathrm{D}$, glacial acetic acid was used, while formic acid was used in experiment E. Reactions using formic acid were inconvenient since an emulsion was formed upon reaction work up. Thus, glacial acetic acid was chosen as the source of organic peroxide for polyol synthesis.

\section{Influence of time on polyol preparation}

When analyzing the influence of the time on the polyol synthesis, it is verified that a broad band around $3440 \mathrm{~cm}^{-1}$ in the IR spectrum for reaction times lower than $360 \mathrm{~min}$ $(6 \mathrm{~h})$ is not present. In contrast, for higher reaction times, the broad band is observed, indicating the formation of hydroxyl groups, and confirming the occurrence of in situ hydroxylation reaction.

It was also noted that as reaction time increases (Figure 2), the iodine index values decrease, indicating a conversion of double bonds present in the oil to the hydroxyl groups with concomitant increase of hydroxyl index. It is worth to mention that an increase in the hydroxyl index with time (20-240 min) was also observed in the hydroxylation reaction of soybean oil using the formic acid/ $\mathrm{H}_{2} \mathrm{O}_{2}$ system. ${ }^{19}$ For a reaction time of $720 \mathrm{~min}$, the lowest value for iodine index and the highest value for hydroxyl index were noted when compared with the other reaction times used, showing a greater conversion of double bonds to hydroxyl groups. Thus, a reaction time of 720 min was set for the multivariate assays.

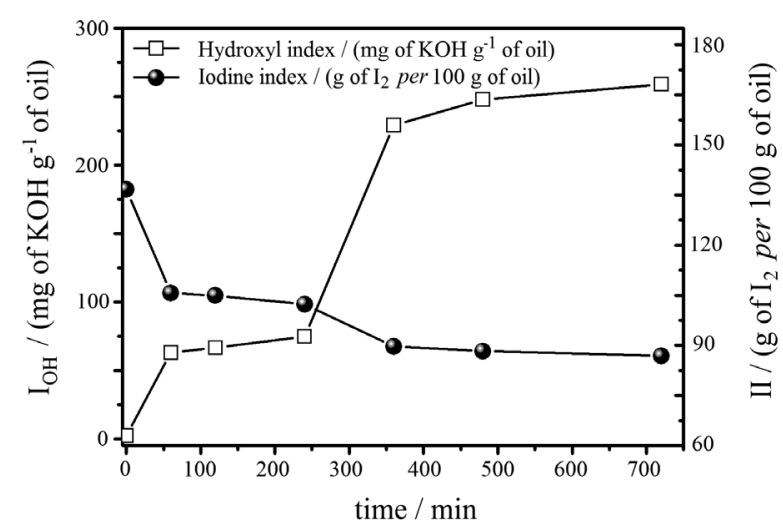

Figure 2. Effect of the reaction time of in situ hydroxylation reaction on the $(\square)$ hydroxyl index and (•) iodine index. Reaction conditions: reaction temperature of $60{ }^{\circ} \mathrm{C}$ after addition of $\mathrm{H}_{2} \mathrm{O}_{2}$ and mol ratio of the reagents of 1 double bond:4.5 of acetic acid: 1.5 of $\mathrm{H}_{2} \mathrm{O}_{2}$ at zero time (unmodified M. fistulifera oil).

Optimization of the hydroxylation reaction of $M$. fistulifera oil

A $2^{2}$ factorial CCD (Table 5) was applied, setting the following experimental conditions: reaction time of $720 \mathrm{~min}$ at $60^{\circ} \mathrm{C}$ (after addition of $30 \%$ hydrogen peroxide), 3 drops of sulfuric acid and $20 \mathrm{~mL}$ of toluene.

Table 5. Responses as a function of the hydroxyl index ( $\mathrm{mg} \mathrm{KOH} \mathrm{g}^{-1}$ of oil) of the $2^{2}$ factorial central composite design (CCD)

\begin{tabular}{|c|c|c|c|c|}
\hline \multirow{2}{*}{ Assay } & \multicolumn{2}{|c|}{ Codified variables } & \multirow{2}{*}{$\begin{array}{c}\text { Response } \\
\mathrm{I}_{\mathrm{OH}} /\left(\mathrm{mg} \mathrm{of} \mathrm{KOH} \mathrm{g}^{-1} \text { of oil }\right)\end{array}$} & \multirow{2}{*}{ Functionality $^{\mathrm{a}}$} \\
\hline & $\mathrm{X}_{1}$ & $X_{2}$ & & \\
\hline 1 & -1 & -1 & 260.3 & 4.04 \\
\hline 2 & 1 & -1 & 140.7 & 2.18 \\
\hline 3 & -1 & 1 & 361.1 & 5.60 \\
\hline 4 & 1 & 1 & 123.5 & 1.91 \\
\hline 5 & -1.414 & 0 & 295.9 & 4.59 \\
\hline 6 & 1.414 & 0 & 164.0 & 2.54 \\
\hline 7 & 0 & -1.414 & 139.1 & 2.16 \\
\hline 8 & 0 & 1.414 & 283.4 & 4.40 \\
\hline 9 & 0 & 0 & 244.3 & 3.79 \\
\hline 10 & 0 & 0 & 245.6 & 3.81 \\
\hline 11 & 0 & 0 & 236.8 & 3.68 \\
\hline 12 & 0 & 0 & 246.8 & 3.83 \\
\hline
\end{tabular}

Reaction conditions: reaction time of 720 min at $60{ }^{\circ} \mathrm{C}$; ${ }^{\text {a mean }}$ functionality $=$ mean molecular weight of oil $\times \mathrm{OH}$ content $\left(\right.$ mequivalent $\left.\mathrm{g}^{-1}\right)$. 
The independent variables studied were the glacial acetic acid and hydrogen peroxide mol ratios, maintaining the ratio of Mabea oil fixed in $1 \mathrm{~mol}$. Based on the value found for the dependent variable (hydroxyl index) for each assay, it was possible to calculate the functionality of the plant polyol obtained. Functionality is an important parameter for the stoichiometric calculation of a future reaction, where plant polyol is considered as a source of raw material for the production of polyurethanes. To achieve this, the plant polyol must react with isocyanate (NCO), which has at least two functional groups (NCO) capable of reacting with active hydrogen of polyols..$^{32}$ Thus, it was sought to analyze the applicability of the plant polyol obtained in the production of polyurethane type polymers.

The quadratic model was fitted to the data related to the $\mathrm{I}_{\mathrm{OH}}$ response by verifying that all linear and quadratic coefficients for the codified variables glacial acetic acid and hydrogen peroxide were significant at $95 \%$ confidence level. The model allowed obtaining the response surface shown in Figure 3. The regression equation describes the behavior of the response depending on the mol ratios of the reagents at $5 \%$ probability. The coefficient of determination $\left(\mathrm{r}^{2}\right)$ obtained was of 0.9049 , confirming the good fit of the model (equation 2)

$$
\begin{aligned}
& \mathrm{I}_{\mathrm{OH}}=243.38-67.97 \mathrm{~A}-6.51 \mathrm{~A}^{2}+ \\
& \text { Error: } \quad \pm 2.25 .96 \mathrm{P}-15.86 \mathrm{P}^{2}-29.50 \mathrm{AP}(2) \\
& \pm 1.59 \quad \pm 1.78 \quad \pm 1.59 \quad \pm 1.78
\end{aligned}
$$

where $\mathrm{A}$ is the codified variable related to the acetic acid ratio and $\mathrm{P}$ is the codified variable related to the hydrogen peroxide ratio.

Analyzing the points in the projection of the response surface (Figure 3), it was possible to determine the different possibilities for plant polyol production. The responses obtained and expressed in hydroxyl contents present values higher than the hydroxyl index that was observed for the crude oil (Table 3), showing that in all assays the desired product was obtained. Assay 3 presented the highest value in the response. However, the choice of the reaction conditions for polyol synthesis must be analyzed according to the purpose of this product.

The product obtained in assay 7 , in which the codified variables correspond to the zero level for variable $\mathrm{X}_{1}$, and -1.414 for variable $\mathrm{X}_{2}$ (Table 5), presents a functionality of approximately 2.0, also observed for assays 2 and 4 . However, in other assays, the functionality of the polyol obtained is greater than 2.0. Besides, depending on the functionality of the polyol, the polymer being synthesized will have different characteristics. This fact has been observed for different polyurethanes derived from soybean, sunflower, canola, corn and linseed polyols. It was found
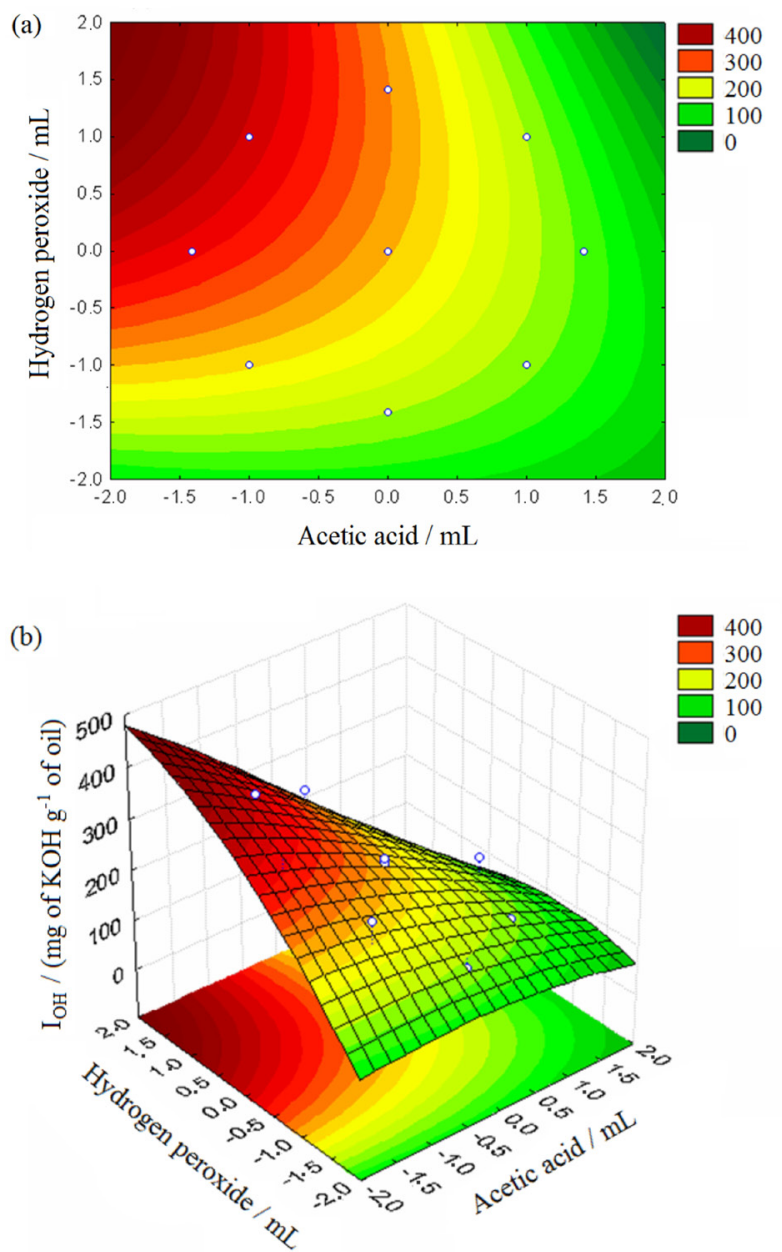

Figure 3. (a) Projection on response surface level for the optimization of the hydroxylation reaction of the oil of M. fistulifera Mart. and (b) response surface.

that polyols derived from canola (functionality 3.3), soybean and corn (functionalities around 3.5) afforded polyurethanes with similar mechanical properties. In the case of linseed polyol (functionality 5.2), the polyurethane derived from it had higher crosslinking density and mechanical properties. ${ }^{33}$

Typically, polyols that produce flexible foams and elastomers have a molecular weight between 1,000 and 6,000 and functionality between 1.8 and 3.0. Such values are observed in assays 2, 4, 6 and 7. Short-chain polyols $(250<$ molecular weight $<1000)$ and high functionality polyols (3-12) produce rigid chains with a high content of cross-links, used in rigid foams and high performance paints. ${ }^{12}$ Functionalities higher than 3.0 are observed in the other assays.

Thus, since the aim of this work is to produce a rigid polymeric material to be used as adsorbent for the treatment of water contaminated by organic compounds, the ratios found with functionality above 3.0 are ideal for such purpose. 


\section{Conclusion}

It was possible to synthesize polyols from the M. fistulifera Mart. oil, a raw material rich in unsaturated fatty acids, essential for polyol production. By means of univariate assays, it was possible to establish the optimum value for the time parameter.

Using a $2^{2}$ factorial central composite design (CCD) for the optimization of the experimental condition regarding the molar ratio of reagents, it was possible to obtain polyols with different functionalities. These products obtained with diversified characteristics can be utilized for the production of polyurethane resins morphologically differentiated.

\section{Supplementary Information}

Supplementary data $\left({ }^{1} \mathrm{H}\right.$ NMR spectrum of the M. fistulifera oil and table presenting the assignments of the principal signals observed, IR spectra for the reactions between M. fistulifera oil, acetic acid (or formic acid) and $\mathrm{H}_{2} \mathrm{O}_{2}$ at different molar ratios, ${ }^{1} \mathrm{H}$ NMR spectra of the epoxidized and hydroxylated $M$. fistulifera oil and IR spectra of the products of the in situ hydroxylation reaction at different reaction times) are available free of charge at http://jbcs.sbq.org.br as PDF file.

\section{References}

1. Okieimen, F. E.; Pavithran, C.; Bakare, I. O.; Eur. J. Lipid Sci. Technol. 2005, 107, 330.

2. Dai, H.; Yang, L.; Lin, B.; Wang, C.; Shi, G.; J. Am. Oil Chem. Soc. 2009, 86, 261.

3. Dixit, A. K.; Kumar, V.; Rani, A.; Manjaya, J. G.; Bhatnagar, D.; Radiat. Phys. Chem. 2011, 80, 597.

4. Mikkola, H.; Pahkala, K.; Ahokas, J.; Biomass Bioenergy 2011, 35, 505.

5. Riveros, C. G.; Mestrallet, M. G.; Gayol, M. F.; Quiroga, P. R.; Nepote V.; Grosso, N. R.; J. Sci. Food Agric. 2010, 90, 2694.

6. Bhatti, I. A.; Ashraf, S.; Shahid, M.; Asi, M. R.; Mehboo, S.; Appl. Radiat. Isot. 2010, 68, 2197.

7. Ghosh, B-S.; Ghosh, S. B.; Sain, M.; J. Polym. Environ. 2010, $18,437$.

8. Martinez, G. M.; Jimenez, R. J.; Cruz, D. R.; Anales del Instituto de Biología, Serie Botânica 2000, 71, 87.

9. Coqueiro, A.; Sarragiotto, M. H.; Zocoler, M. A.; Vidotti, G. J.; Biochem. Syst. Ecol. 2007, 35, 717.

10. Daud, R. D.; Fere, R. J. F.; Rev. Bras. Zool. 2004, 21, 453.

11. http://cenbio.iee.usp.br/saibamais/bancobiomassa/bibliografia. htm acessed in October 2011.
12. Vilar, W. D.; Química e Tecnologia de Poliuretanos, 3a. ed.; Vilar Consultoria Técnica Ltda: Rio de Janeiro, Brasil, 2005.

13. Lathi, P. S.; Mattiasson, B.; Appl. Catal., B 2007, 69, 207.

14. Lin, B.; Yang, L.; Dai H.; Yi, A.; J. Am. Oil Chem. Soc. 2008, $85,113$.

15. Tran, P.; Graiver, D.; Narayan, R.; J. Am. Oil Chem. Soc. 2005, $82,653$.

16. Narine, S. S.; Yue, J.; Kong, X.; J. Amer. Oil Chem. Soc. 2007, $84,173$.

17. Guo, A.; Demydov, D.; Zhang, W.; Petrovic, Z. S.; J. Polym. Environ. 2002, 10, 49.

18. Guo, A.; Zhang, W.; Petrovic, Z. S.; J. Mater. Sci. 2006, 41, 4914.

19. Monteavaro, L. L.; Silva, E. O.; Costa, A. O.; Samios, D.; Gerbase, A. E.; Petzhold, C. L.; J. Am. Oil Chem. Soc. 2005, $82,365$.

20. Martinelli, M.; Luca, M. A.; Bechi, D. M.; Mitidieri, S.; J. Sol-Gel Sci. Technol. 2009, 52, 202.

21. Campanella, A.; Baltanás, M. A.; Catal. Today 2005, 107, 208

22. Komintarachat, C.; Chuepeng, S.; Am. J. Appl. Sci. 2010, 7, 1073.

23. Adams, R. P.; Identification of Essential Oil Components by Gas Chromatography/Mass Spectroscopy, $2^{\text {nd }}$ ed.; Allured Publishing Corporation: Illinois, 1995.

24. Moretto, E.; Fett, R.; Óleos e Gorduras Vegetais (Processamentos e Análises), 2a. ed.; Editora da UFSC: Florianópolis, Brasil, 1989.

25. Aslan, S.; Immirzi, B.; Laurienzo, P.; Malinconico, M.; Martuscelli, E.; Volpe M. G.; Pelino, M.; and Savini, L.; J. Mater. Sci. 1997, 32, 2329.

26. Gooch, E. E.; Chem. Educator 2001, 6, 7.

27. Box, G. E. P.; Hunter, W. G.; Hunter, J. S.; Statistic for Experimenters: An Introduction to Design, Data Analysis and Model Building, $1^{\text {st }}$ ed.; Wiley: New York, 1978.

28. Kirschenbauer, H. G.; Fats and Oils: An outline of their Chemistry and Technology, $2^{\text {nd }}$ ed.; Chapman \& Hall: London, 1960.

29. Ma, F.; Hanna, M. A.; Bioresour. Technol. 1999, 70, 1.

30. Osawa, C. C.; Gonçalves, L. A. P.; Quim. Nova 2006, $29,593$.

31. www.lipidlibrary.co.uk/index.html accessed in Febraury 2011.

32. Lopes, R. V. V.; Zamian, J. R.; Resck, I. S.; Sales, M. J. A.; Santos, M. L.; Cunha, F. R.; Eur. J. Lipid Sci. Technol. 2010, $112,1253$.

33. Zlatanić, A.; Lava C.; Zhang, W.; Petrović, Z. S. J.; Polym. Sci., Part B: Polym. Phys. 2004, 42, 809.

Submitted: December 24, 2011 Published online: June 12, 2012 


\title{
Synthesis of Polyols from Mabea fistulifera Mart. (Euphorbiaceae) Oil
}

\author{
Julieta J. da Silveira Neta, ${ }^{* a, b}$ Carlos J. da Silva, ${ }^{b}$ Róbson R. Teixeira, ${ }^{b}$ César Reis, ${ }^{b}$ \\ Efraim L. Reis ${ }^{b}$ and Amanda M. Teixeira ${ }^{b}$
}

${ }^{a}$ Embrapa Amazônia Oriental, Trav. Dr. Enéas Pinheiro s/n, 66095-100 Belém-PA, Brazil

${ }^{b}$ Departamento de Química, Universidade Federal de Viçosa, Av. P. H. Rolfs s/n, 36570-000 Viçosa-MG, Brazil

\begin{tabular}{|c|c|c|}
\hline Signal number & $\begin{array}{c}\text { Chemical shift } \\
\delta / \mathrm{ppm}\end{array}$ & Assignment \\
\hline 1 & 7.25 & $\mathrm{CHCl}_{3}$ \\
\hline 2 & 5.35 & $\mathrm{CH}=\mathrm{C} H$ \\
\hline 3 & 5.25 & $-\mathrm{CHOCOR}$ \\
\hline 4 & $4.30-4.10$ & $-\mathrm{CH}_{2} \mathrm{OCOR}$ \\
\hline 5 & 2.76 & $\mathrm{CH}=\mathrm{CHCH}_{2} \mathrm{CH}=\mathrm{CH}$ \\
\hline 6 & 2.30 & $-\mathrm{COCH}_{2}$ \\
\hline 7 & 2.03 & $-\mathrm{CH}_{2} \mathrm{CH}=\mathrm{CH}$ \\
\hline 8 & 1.59 & $-\mathrm{COCH}_{2} \mathrm{CH}_{2}$ \\
\hline 9 & 1.30 & $\left(\mathrm{CH}_{2}\right)_{\mathrm{n}}$ \\
\hline 10 & 0.97 & $\mathrm{CH}=\mathrm{CHCH}_{2} \mathrm{CH}_{3}$ \\
\hline 11 & 0.89 & $\mathrm{CH}_{3}$ \\
\hline
\end{tabular}

$\mathrm{R}$ : alkyl portion of the tryacylglycerides.

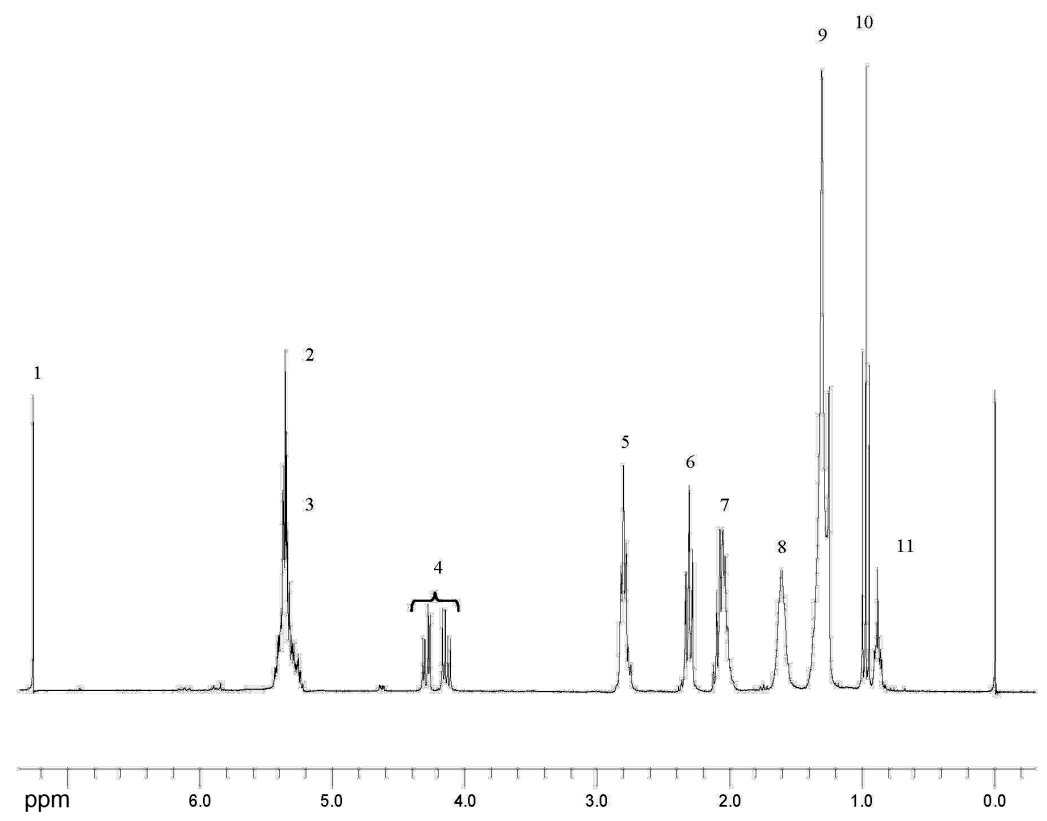

Figure S1. ${ }^{1} \mathrm{H}$ NMR spectrum $\left(\mathrm{CDCl}_{3}, 300 \mathrm{MHz}\right)$ of M. fistulifera oil.

*e-mail: julieta_neta@yahoo.com.br, julieta@cpatu.embrapa.br 

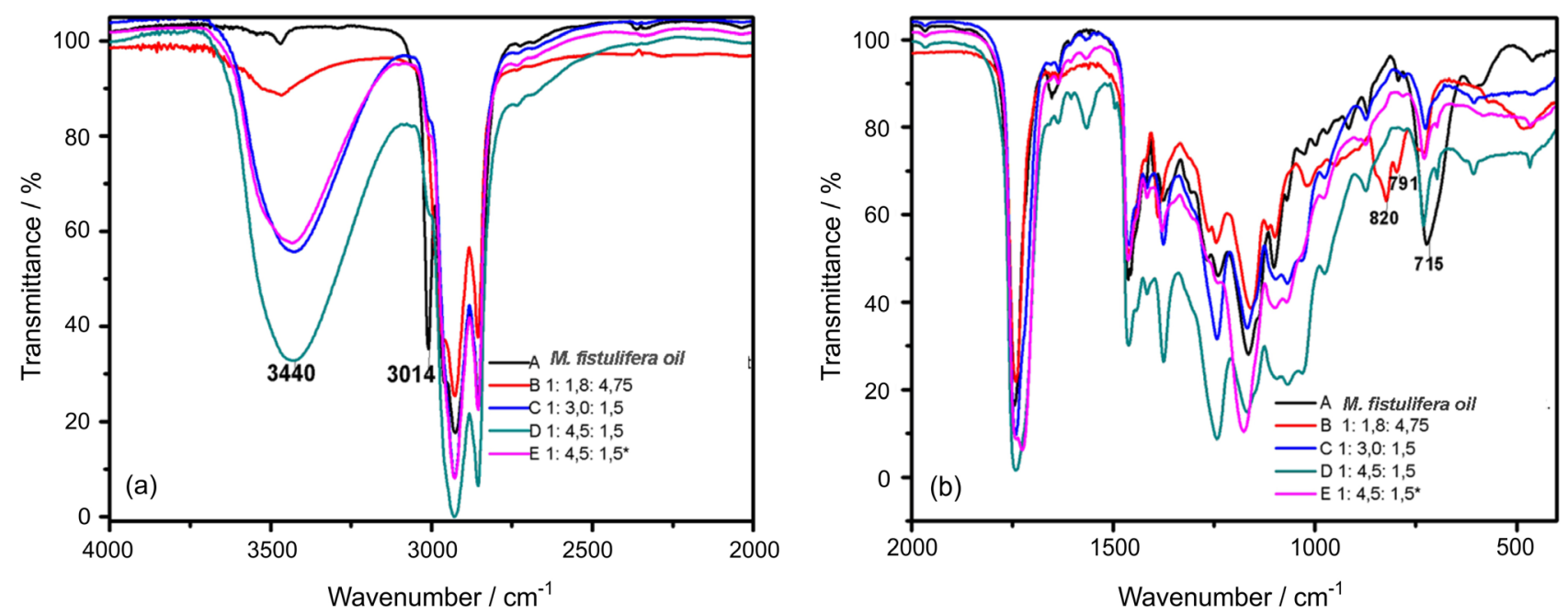

Figure S2. Spectra in the IR region: (a) 4000-2000 $\mathrm{cm}^{-1}$, (b) $2000-500 \mathrm{~cm}^{-1}$, for the reactions between M. fistulifera oil, acetic acid (or formic acid) and $\mathrm{H}_{2} \mathrm{O}_{2}$ at different molar ratios.

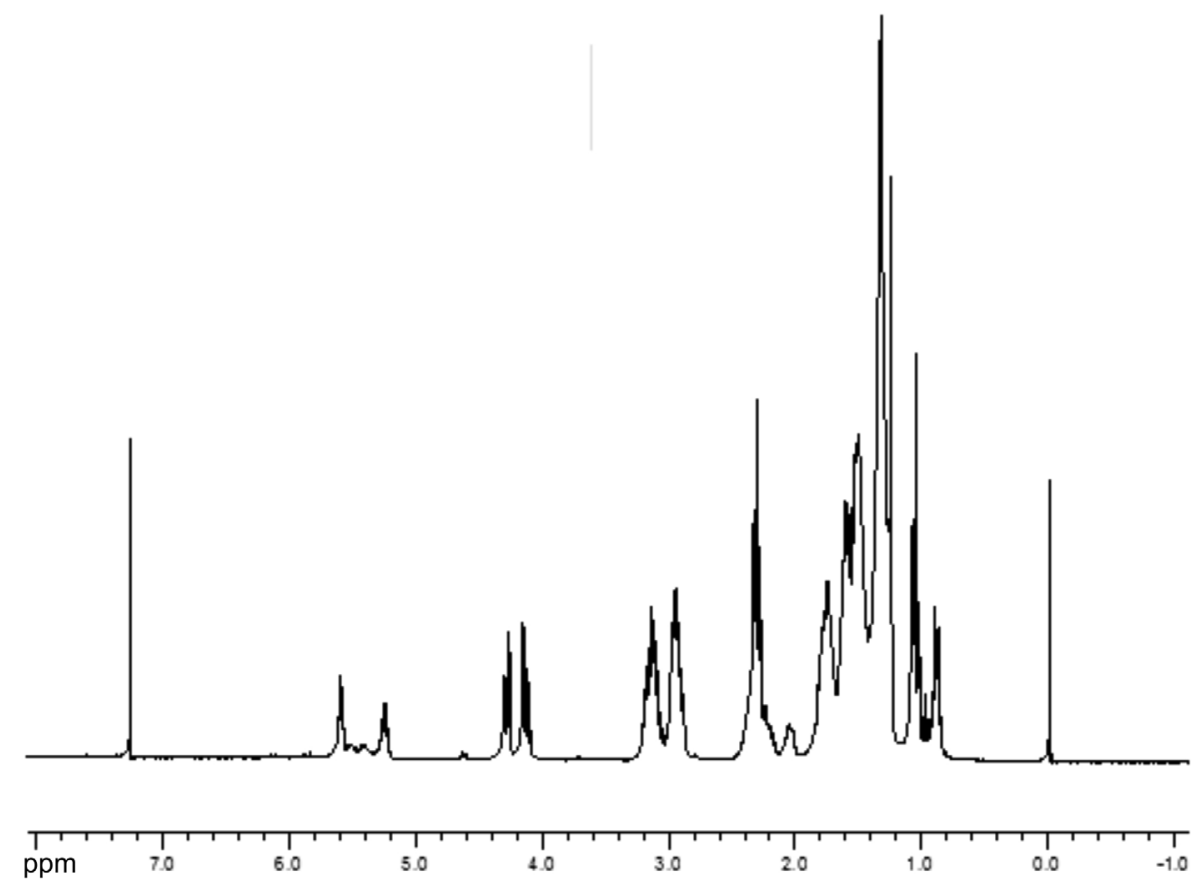

Figure S3. ${ }^{1} \mathrm{H}$ NMR spectra $\left(\mathrm{CDCl}_{3}, 300 \mathrm{MHz}\right)$ to epoxidized $M$. fistulifera oil (molar ratio of oil/acetic acid/ $\mathrm{H}_{2} \mathrm{O}_{2}$ of 1:1.8:4.75) 


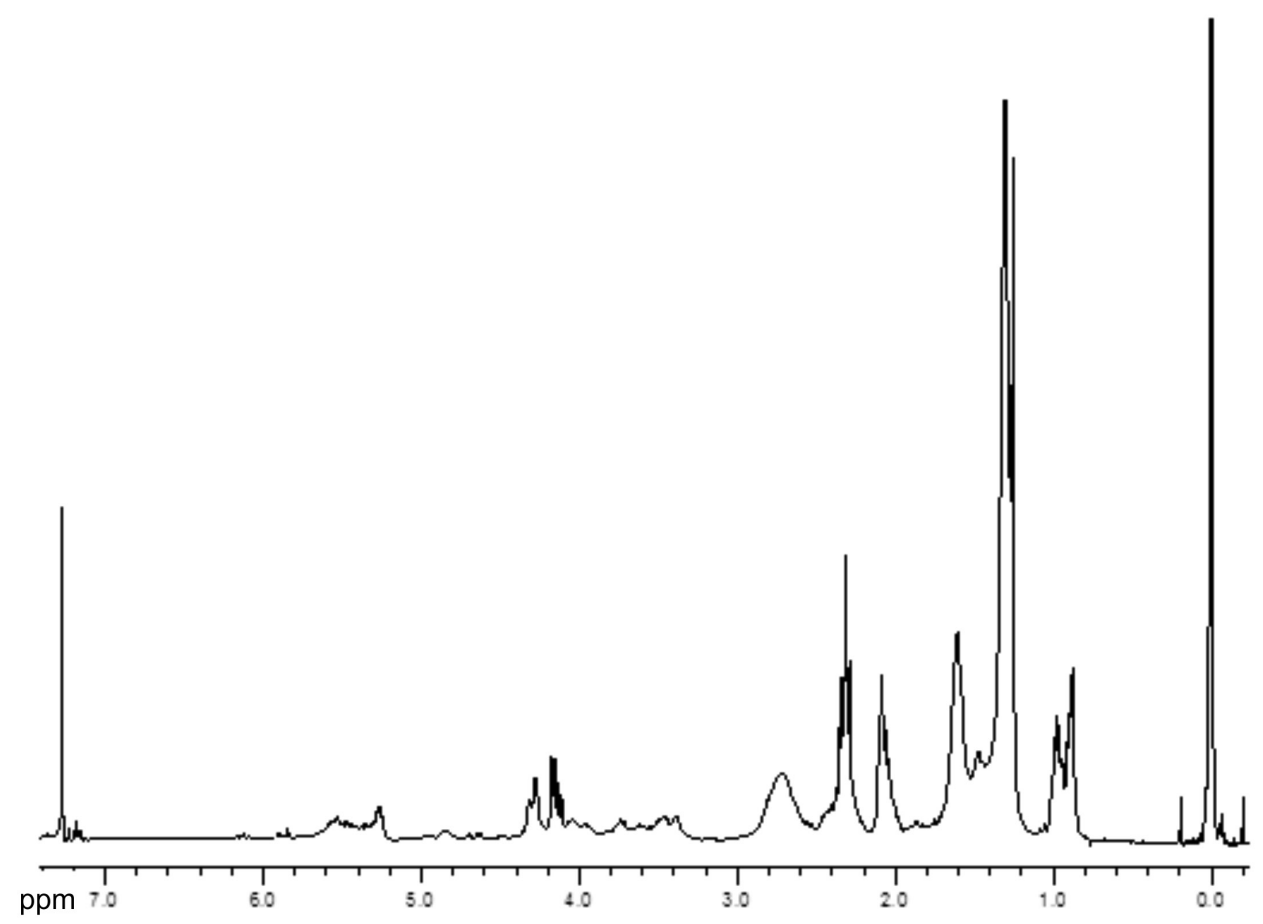

Figure S4. ${ }^{1} \mathrm{H}$ NMR spectra $\left(\mathrm{CDCl}_{3}, 300 \mathrm{MHz}\right)$ to hydroxylated $M$. fistulifera oil (molar ratio of oil /acetic acid/ $\mathrm{H}_{2} \mathrm{O}_{2}$ of 1:4.5:1.5).

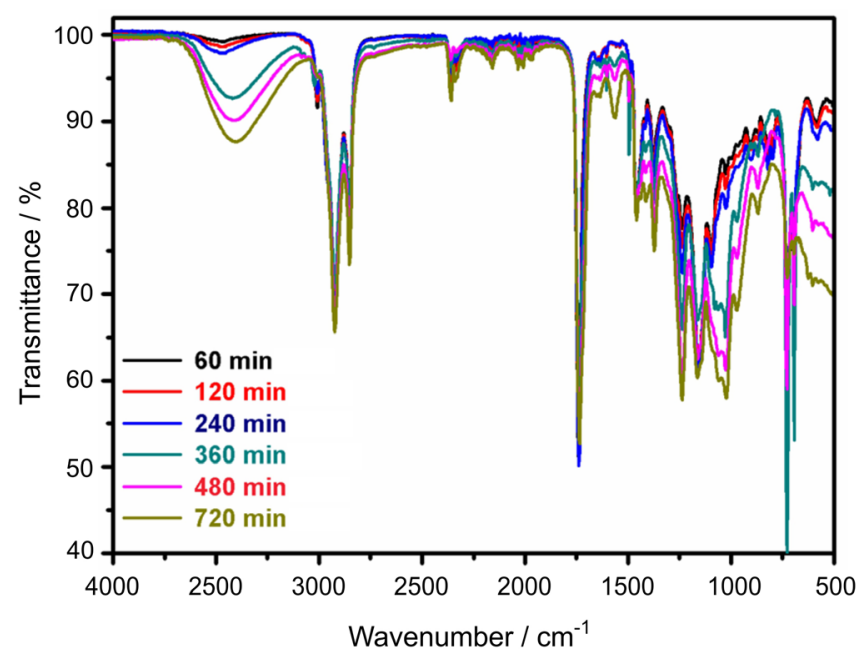

Figure S5. Infrared spectra $\left(4000-500 \mathrm{~cm}^{-1}\right)$ of the products of the in situ hydroxylation reaction at different reaction times. 